\title{
Noções de história em Pedro Calmon
}

\section{Alesson R. Rota}

\section{Resumo}

A pesquisa Noções de história em Pedro Calmon tem como objetivo mapear as principais ideias do autor sobre a história a partir dos prefácios de seus livros. Trata-se de uma aventura tortuosa por conta das inúmeras obras publicadas em um extenso recorte temporal, mas que possibilita noções gerais sobre o pensamento teórico do autor.

\section{Palavras-chave}

Teoria da História, Historiografia, Pedro Calmon

\section{Introdução}

Pedro Calmon é um dos interpretes do Brasil pouco estudado na era contemporânea da historiografia brasileira. Contudo, ocupou lugares de destaque em seu tempo, na acadêmica brasileira de letras, publicando livros no brasil e no exterior, produzindo livros para o governo, sendo reitor da Universidade do Distrito Federal etc. Por enquanto, a pesquisa não se encarrega de questionar os motivos do esquecimento de Calmon, devido a fase inicial que se encontra, é preferível mapear quais os tipos de raciocínios teóricos que compõem o pensamento do autor.

\section{Resultados e Discussão}

Registra-se aqui dois historiadores que estudaram Calmon em perspectiva historiográfica. São eles José Carlos Reis e Arno Wehling. A começar por Reis, Calmon é entendido fundamentalmente como herderiano por sustentar uma "evolução natural para o país" (REIS, 2006: 39), como se houvesse um destino a ser cumprido. Wehling afirma que Calmon "se situava na tradição histórica de Rank, Herder, Herculano e Varnhagem", (WEHLING: 1999, p. 608), mas vê no autor leituras mais recentes, como a de Raymond Aron, por conta de um certo "relativismo" em relação ao ponto de vista do historiador.

As constatações de Reis e Wehling não vão contra as considerações que foram obtidas nessa pesquisa, pelo contrário, são complementares. Há nos prefácios dos livros citações e trechos evidentes que remetem principalmente a Herder. Todavia, a partir da leitura dos prefácios, foi possível enxergar uma gama mais plural no pensamento de Calmon, que incluem as reflexões sobre o objeto da história de Robin Collingwood e a síntese narrativa de Henri Berr.

Os prefácios dos livros analisados foram: História da Civilização brasileira (1933), Pequena História da Civilização Brasileira (1936) História da Bahia (1927), História Social do Brasil, Espírito da Sociedade Colonial (1935), Espírito da Sociedade Imperial (1937) e a Época Republicana (1939), História do Brasil As Origens (1939), História do Brasil A formação (1941), Brasil e América: história de uma política (1944), e História do Brasil (1959). A análise dos prefácios enquanto fonte de pesquisa é problemática. Conforme analisa Nicolazzi, "o prefácio permite que ele [o autor] apareça de maneira plena, justamente para fechar a obra, completando seus vazios, sem prejuízo para o estatuto objetivo do texto. (NICOLAZZI: 2011, 99) Isso implica que não há necessariamente uma linearidade clara entre a narrativa do prefácio e a narrativa do restante obra, como se o autor falasse de outro lugar e em outro momento previamente analisando e julgando o texto a ser lido, de modo que direcione a apreciação do leitor.

Sabendo da complexidade que envolve constituir uma pesquisa a partir de prefácios, enfrentei o desafio para esboçar linhas gerais sobre o pensamento de Calmon, mas jamais concluir seu pertencimento a um movimento historiográfico.

\section{Conclusões}

A pesquisa por ora realizada permitiu constatar apropriações de Calmon as diversas outras influencias que se somam as já mapeadas pela historiografia especializada. Cita-se as apropriações de Collingwood, Berr, Lucien Febvre, Herin Bergson e Jules Michelet. A partir disso, a pesquisa visará a análise da narrativa histórica em uma perspectiva plural, que leva em consideração noções sociológicas, filosóficas, educacionais e política presentes em Calmon.

NICOLAZZI, Fernando. Um estilo de História. A Viagem, A memória, O Ensaio: sobre Casa Grande e Senzala e a representação do passado. São Paulo: Unesp, 2011.

REIS, José Carlos. Pedro Calmon e a visão romântica e cristã da nação brasileira. IN: As identidade do Brasil - de Calmon a Bomfim. Rio de Janeiro, RJ: FGV 2006. p. 33-84

WEHLING, Arno. A historiografia em Pedro Calmon. IN: RIHGB, Rio de Janeiro, 147 (351): 353-361, jul/set, 1999 